INTERNATIONAL JOURNAL OF INNOVATION IN ENTERPRISE SYSTEIM

Journal homepage: https://ijies.sie.telkomuniversity.ac.id/index.php/IJIES/index

\title{
Developing Strategies to Improve Business Model of Online Laundry Marketplace Startup
}

\author{
Taqyya Naufinda Asnin ${ }^{1 *}$, Yudha Prambudia ${ }^{2}$, Rosad Ma'ali El Hadi ${ }^{3}$ \\ 1,2,3 Telkom University \\ J1. Telekomunikasi No.1, Bandung, 40258, Indonesia \\ *taqyyana@gmail.com
}

ARTICLE INFO

Article history:

Received 29 June 2021

Accepted 28 July 2021

Published 31 July 2021

Keywords:

Infineeds; Business Model

Strategy; SWOT Analysis;

Quantitative Strategic

Planning Matrix.

\section{Introduction}

Micro, Small \& Medium Enterprises (MSMEs) is one of the actors who play a role in economic growth in Indonesia. According to the databoks, according to the Ministry of Cooperatives, Small and Medium Enterprises, MSMEs have contributed greatly to the gross domestic product (GDP) which has increased significantly every year since 2010-2018 to reach Rp8,573.9 trillion [1]. The contribution of MSMEs to the economy in Indonesia can be seen in Fig.1.

Currently, the internet is considered a major driving force in the development of the business world [2]. Director of Information and Communication for the Economy and Maritime Affairs of the Ministry of Communication and Information, Septriana Tangkary, 9.4 million of the total 60 million MSMEs in Indonesia have gone online [3]. The data shows that there are still around $84 \%$ of MSMEs that still do not use technology for their business development, especially in the field of laundry services [4]. 


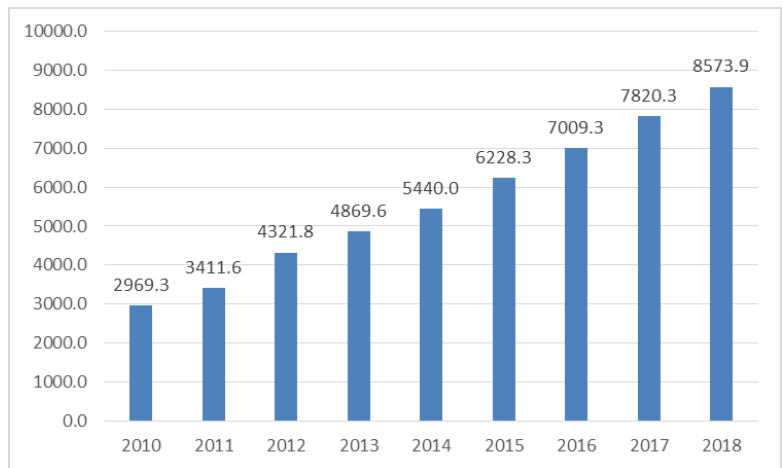

Fig. 1 - Contribution of MSMEs to the economy in Indonesia 2010-2018 [5]

According to the Indonesian Laundry Association (ASLI) there are around 132,000 laundry services in Indonesia and the number continues to grow [6]. The development of this number of laundry services can lead to quite tight competition with its competitors, especially to get customers.

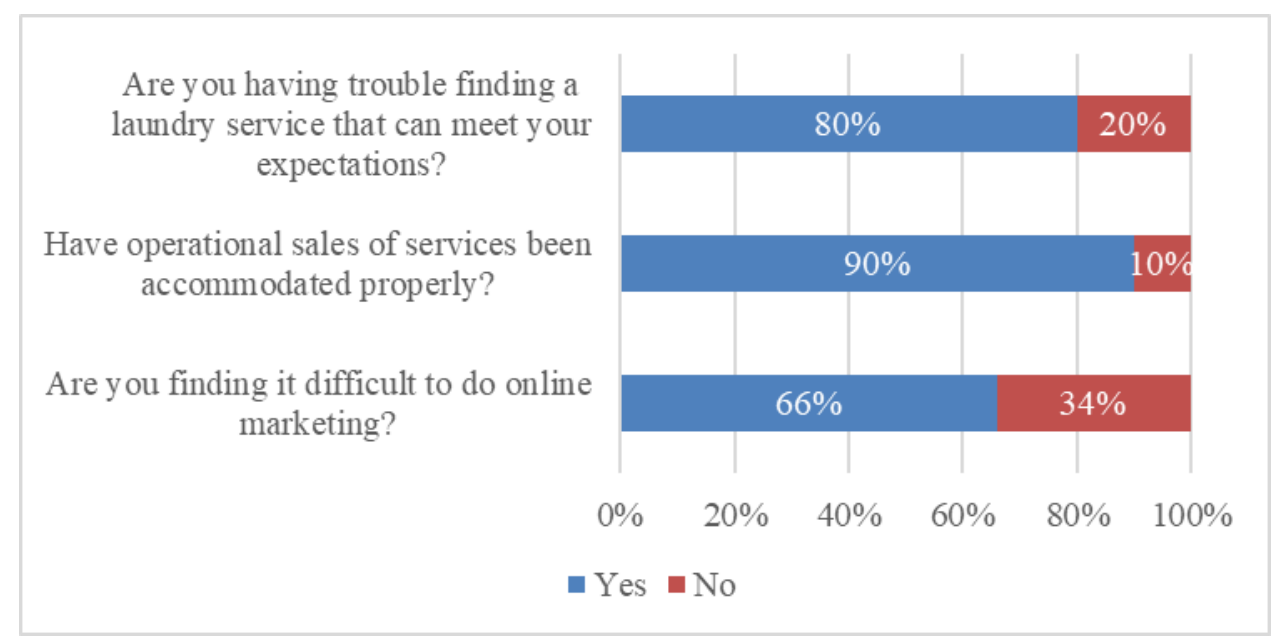

Fig. 2 - Preliminary Survey Results

Fig.2 shows the results of the preliminary survey. The survey was conducted on 30 MSMEs laundry service providers and college students in Bandung. 66\% of service providers find it difficult to market their services online and $90 \%$ say that operationally their service sales have not been accommodated or monitored properly. Meanwhile, in terms of seekers of laundry services, as many as $80 \%$ of the total interviewees said that they had difficulty finding and ordering services that were still conventional, because of that, laundry service users often said the laundry services they found did not meet their expectations, especially in terms of quality.

Infineeds is a startup that stands as an online marketplace for household services or household needs, especially in the field of laundry services or washing clothes in Bandung in 2020. Starting from the problems raised by laundry service providers and seekers, Infineeds seeks to simplify laundry service sales activities in terms of their marketing and operations and search for laundry services that meet expectations with the help of standardized information technology. As a newcomer startup in the field of online marketplace services, Infineeds needs to provide unique value offered to consumers compared to its competitors, however, Infineeds is still unable to identify this unique value so that it can be superior to its competitors. In addition, Infineeds is also a startup company so the market has not yet been formed.

These factors pose a challenge to Infineeds' sustainability. Therefore, this study seeks to solve the problem of Infineeds which does not have a unique value and the market has not yet been formed by formulating a business development strategy to deal with these conditions and obtain a clearer market. Business development strategies are also carried out by knowing the business model used by the company [7]. One of the business model approaches that can be used is the business model canvas (BMC). The development strategy is formulated using a SWOT approach to obtain alternative development strategies and identify priorities for alternative development strategies using the quantitative strategic planning matrix (QSPM). This study offers several business development strategies to Infineeds hoping that the company can develop sustainably and new data for further research on similar topics. 


\section{Theoretical Framework}

\subsection{Business Model Canvas}

Business model canvas or BMC is a tool used to describe, visualize, assess, and change business models [8]. BMC is considered one of the tools that can make it easier for readers to understand the content and intent of the canvas itself because of its uniqueness which is able to show it visually [9]. BMC can be used as a business development model for IoT businesses and information services [7]. BMC is described as 9 element blocks. An overview of the nine business model canvas blocks can be seen in Fig.3.

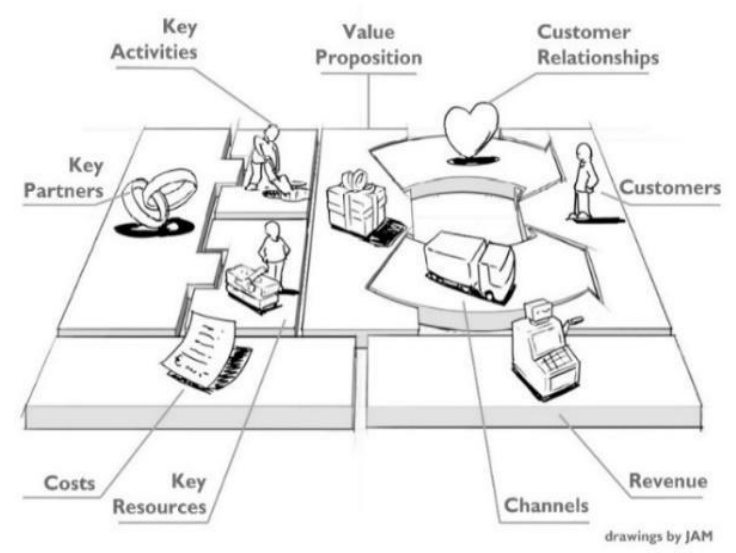

Fig. 3 - Business Model Canvas [8]

\subsection{Strength, Weakness, Opportunity, Threat (SWOT)}

SWOT is a tool used for strategic planning and strategic management in an organization [10]. SWOT analysis is the identification of various factors systematically to formulate corporate strategy [11]. The SWOT diagram aims to compare the external factors of opportunities (opportunities) and threats (threats) with internal factors of strengths (strengths) and weaknesses (weaknesses). The results of the comparison of two factors, namely external and internal, are then compared in a SWOT analysis Cartesian diagram as shown in Fig.4.

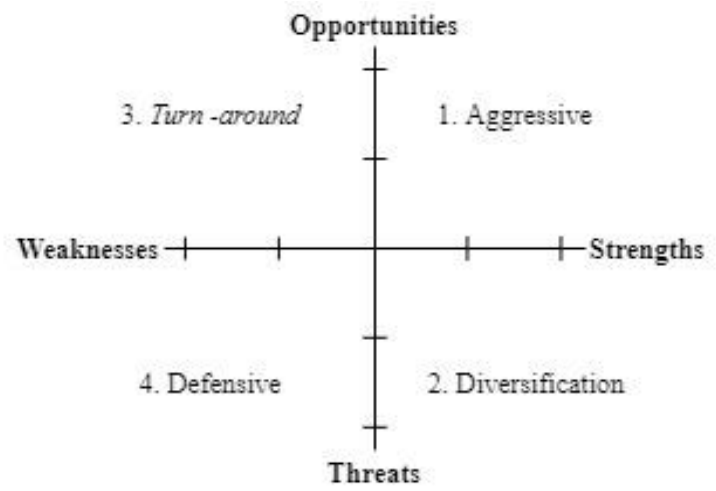

Fig. 4 - SWOT analysis diagram

It is necessary to calculate the EFAS and IFAS scores to determine the strategic position. The formula to calculate the EFAS and IFAS scores is as follows [12]:

1. $\mathrm{X}$ coordinates $=$ total score of strength - total score of weakness

2. $\mathrm{Y}$ coordinates $=$ total score of opportunity - total score of threat

\subsection{Quantitative Strategic Planning Matrix (QSPM)}

A quantitative strategic planning matrix or QSPM is a tool that can help evaluate various alternatives by considering intuitive internal and external factors [13]. QSPM can be the result of strategic decisions from the attractiveness score (AS) of both internal and external factors, then the total attractiveness score (TAS) is obtained from the multiplication of weights and AS [14]. 


\subsection{State of The Art}

There are many types of research on developing strategies for new companies using a combination of BMC and SWOT analysis methods for example [15] and [18] used the combination to evaluate and design a business model for food and beverage companies. Others [16] use it to develop a strategy for an outsourcing company while [17] use the combination for fashion SME. More recent research from [19] uses it for a company whose product is an air refresher. This research adds to the collection of the use of the combined method a new application. The combined method is applied to develop strategies for improving a startup company that offers a marketplace for laundry service. Table 1 below presents the relevant previous research.

Table 1 - State of The Art

\begin{tabular}{|c|c|c|c|c|c|}
\hline No & Title & Year & Object & Author & Method and Result \\
\hline 1 & $\begin{array}{l}\text { Business Model } \\
\text { Evaluation and Design } \\
\text { Based on Business } \\
\text { Model Canvas }\end{array}$ & 2015 & Cake industry & $\begin{array}{c}\text { Elizabeth Cindy } \\
\text { Tjitradi [15] }\end{array}$ & $\begin{array}{l}\text { The result of this study is to evaluate } \\
\text { the current business model of the cake } \\
\text { industry and propose a future business } \\
\text { model using the BMC approach }\end{array}$ \\
\hline 2 & $\begin{array}{c}\text { The Rhythm of } \\
\text { Empowerment Business } \\
\text { Development Strategy } \\
\text { Through Business } \\
\text { Model Canvas } \\
\text { Approach }\end{array}$ & 2018 & $\begin{array}{l}\text { Outsourcing } \\
\text { company }\end{array}$ & $\begin{array}{l}\text { Budi Bagus } \\
\text { Prasetyo, Lukman } \\
\text { M. Baga, Lilik } \\
\text { Noor Yuliati [16] }\end{array}$ & $\begin{array}{l}\text { This study combines the BMC method } \\
\text { with SWOT Analysis to design a future } \\
\text { business model of an outsourcing } \\
\text { company }\end{array}$ \\
\hline 3 & $\begin{array}{l}\text { Designing Business } \\
\text { Model Atelier Prana } \\
\text { Using Business Model } \\
\text { Canvas Approach }\end{array}$ & 2018 & Fashion SME & $\begin{array}{c}\text { Khalif Abdul Aziz, } \\
\text { Sari Wulandari, } \\
\text { Boby Hera Sagita } \\
\text { [17] }\end{array}$ & $\begin{array}{l}\text { This study combines the BMC method } \\
\text { with SWOT Analysis using } 4 \\
\text { dimensions approach (value } \\
\text { proposition, cost of revenue, } \\
\text { infrastructure, and customer relations) } \\
\text { to develop a business model of a } \\
\text { Fashion SME }\end{array}$ \\
\hline 4 & $\begin{array}{l}\text { Strategic Analysis Using } \\
\text { SWOT Method and } \\
\text { QSPM (Quantitative } \\
\text { Strategy Planning } \\
\text { Matrix): A Case Study } \\
\text { on D'Gruz Caffe in } \\
\text { Bluto Sumenep District }\end{array}$ & 2020 & $\begin{array}{l}\text { Coffee shop } \\
\text { company }\end{array}$ & Ariza Qanita [18] & $\begin{array}{l}\text { The study uses SWOT and QSPM to } \\
\text { analyze a coffee shop company's } \\
\text { current strategy and recommend an } \\
\text { alternative strategy }\end{array}$ \\
\hline 5 & $\begin{array}{l}\text { Business Development } \\
\text { Strategy "COFRESH" } \\
\text { Product Using Business } \\
\text { Model Canvas (BMC) } \\
\text { and SWOT Analysis }\end{array}$ & 2020 & $\begin{array}{l}\text { Air freshener } \\
\text { company }\end{array}$ & $\begin{array}{l}\text { Nita Kuswardhani, } \\
\text { Rizki Agustian, } \\
\text { Melinda Lady Plus } \\
\text { [19] }\end{array}$ & $\begin{array}{l}\text { This study combines the method of } \\
\text { QSPM and BMC to develop a business } \\
\text { model strategy for air freshener } \\
\text { company }\end{array}$ \\
\hline
\end{tabular}

\section{Methodology}

\subsection{Data Collection Stage}

Before collecting data, it is necessary to identify the data needed, namely data from Infineeds' existing business model and data from the external and internal business environment. The existing business model was obtained by conducting interviews with the owner or chief executive officer (CEO) of Infineeds. The interview was conducted by giving several questions to the CEO of Infineeds using an approach according to the 9 element blocks of the business model canvas. Internal factors are obtained from interviews while external factors are obtained from interviews and secondary data. 


\subsection{Data Processing Stage}

Previous studies show that the business model canvas or BMC is widely used as a method of business model analysis and planning as well as business development strategies. EFAS and IFAS questionnaires were made to gain scores of the company's internal and external environment. The scores then become an input for the SWOT analysis diagram to determine the company's current position so that the selection of the type of strategy can be adjusted based on the SWOT analysis Cartesian diagram. SWOT matrix is needed to obtain alternative business development strategies by analyzing the company's SWOT Factors. The QSPM questionnaire was created to determine the priority of alternative development strategies based on the attractiveness value of each SWOT factor against alternative development strategies. The respondents for both EFAS-IFAS and QSPM questionnaires are five Infineeds employees who have decision-making authority.

\section{Result and Discussion}

The existing business model gained from the data collection stage will be grouped into 9 structured or blocks of BMC that are shown in Table 2. After identifying the existing BMC and business environment, the next step is to conduct a SWOT analysis. Table 3 shows the result of the SWOT analysis.

Table 2 - Existing BMC of Infineeds

\begin{tabular}{|c|c|c|c|c|}
\hline \multicolumn{5}{|c|}{ Proposed BMC for Infineeds } \\
\hline \multirow{2}{*}{$\begin{array}{c}\text { Key } \\
\text { partnership } \\
\text { Laundry } \\
\text { (MSMEs), } \\
\text { laundry } \\
\text { entrepreneur } \\
\text { community } \\
\text { and forum }\end{array}$} & $\begin{array}{c}\text { Key activities } \\
\text { App usage training, quality } \\
\text { standardization }\end{array}$ & \multirow{2}{*}{$\begin{array}{c}\text { Value } \\
\text { propositions } \\
\text { Website based } \\
\text { applications, } \\
\text { increase the } \\
\text { productivity of } \\
\text { business partners }\end{array}$} & $\begin{array}{c}\text { Customer relationship } \\
\text { Giveaway, free education, } \\
\text { promo, and discount }\end{array}$ & \multirow{2}{*}{$\begin{array}{l}\text { Customer } \\
\text { segments } \\
\text { Students, } \\
\text { laundry } \\
\text { (MSMEs) }\end{array}$} \\
\hline & $\begin{array}{l}\text { Key resources } \\
\text { Support system, } \\
\text { Human resources }\end{array}$ & & $\begin{array}{c}\text { Channels } \\
\text { Social media, print media, } \\
\text { influencer }\end{array}$ & \\
\hline \multicolumn{3}{|c|}{$\begin{array}{l}\text { Cost structure } \\
\text { (wages, rental of web and server offices, } \\
\text { riable cost (office supplies, advertising, cast, } \\
\text { etc.) }\end{array}$} & \multicolumn{2}{|c|}{$\begin{array}{c}\text { Revenue streams } \\
\text { Subscription, sharing profit, a convenience fee }\end{array}$} \\
\hline
\end{tabular}

The internal factors of Infineeds' strengths and weaknesses and the external factors of Infineeds' opportunities and threats from SWOT analysis are then weighted and rated to obtain IFAS and EFAS scores. The questionnaire data was then processed with the results as shown in Table 4.

At the stage of data processing, the IFAS and EFAS matrix scores of each SWOT factor were obtained with a total score on the internal strength factor of 1.86 and the weakness of 0.95 , while the score on the external factor of opportunity was 1.53 and the threat was 1.38. These scores then become the benchmark in determining the right position of the development strategy in Infineeds based on the SWOT diagram with the following calculations:

1. $\mathrm{X}$ coordinate $=$ total score of strength - total score of weakness $=1.86-0.95=0.91$

2. $\mathrm{Y}$ coordinates $=$ total score of opportunities - total score of threat $=1.53-1.38=0.15$

The calculation results of internal and external factor scores based on the IFAS and EFAS matrices are then applied to a SWOT analysis diagram as shown in Fig. 5.

Table 3 - SWOT Analysis of Infineeds

\begin{tabular}{|c|c|}
\hline Strength Factors & Symbol \\
\hline Guaranteed transaction security & S1 \\
\hline Transactions are easier and faster without having to transfer via mobile banking or ATM & $\mathrm{S} 2$ \\
\hline Have an experienced team of more than 1-2 years in their respective fields & S3 \\
\hline Easy access to websites and applications both on-demand and real-time on various devices & S4 \\
\hline Incessantly publishing educational and entertainment content on social media & S5 \\
\hline
\end{tabular}




\begin{tabular}{lc}
\hline \multicolumn{1}{c}{ Weakness Factors } & Symbol \\
\hline Do not have a legal entity and business license so that it raises doubts for customers and business partners & W1 \\
\hline $\begin{array}{l}\text { HR management is still carried out by the CEO centrally as a decision-maker due to the lack of natural } \\
\text { resources who are experts in the field of human resources and a work culture that has not been fully formed }\end{array}$ & W2 \\
\hline $\begin{array}{l}\text { Quality standards from service providers (partners) cannot be monitored directly just because through } \\
\text { reviews }\end{array}$ & W3 \\
\hline Not yet developing iOS and Android-based apps & W4 \\
\hline \multicolumn{1}{c}{ Threat Factors } & Symbol \\
\hline Trends in the needs of people who want everything practical & O1 \\
\hline Support from the go-digital era and the trend of e-commerce usage in Indonesia & O3 \\
\hline The desire of laundry SMEs who want to reach wider consumers in the digitalization era & O4 \\
\hline Internet users in Indonesia are increasing & Symbol \\
\hline & T1 \\
\hline Consumer loyalty to similar businesses that have been running for a long time & T2 \\
\hline $\begin{array}{l}\text { Laundry service providers prefer to use platforms that have been around for a long time because they are } \\
\text { adaptive }\end{array}$ & T3 \\
\hline Security attacks or hacks from hackers & T4 \\
\hline $\begin{array}{l}\text { The mindset of people who think that using other people's services is considered a luxurious and lazy } \\
\text { lifestyle }\end{array}$ & T5 \\
\hline The technology used is still below existing and long-running competitors & \\
\hline
\end{tabular}

Table 4- IFAS and EFAS scores

\begin{tabular}{|c|c|c|c|c|}
\hline \multicolumn{2}{|r|}{ Internal } & \multirow{2}{*}{ Weight } & \multirow{2}{*}{ Rating } & \multirow{2}{*}{ Score } \\
\hline No & Strengths Factor & & & \\
\hline 1 & $\mathrm{~S} 1$ & 0.12 & 3.2 & 0.376471 \\
\hline 2 & S2 & 0.12 & 3.2 & 0.376471 \\
\hline 3 & S3 & 0.10 & 3.6 & 0.365775 \\
\hline 4 & S4 & 0.12 & 3.4 & 0.4 \\
\hline 5 & S5 & 0.11 & 3 & 0.336898 \\
\hline \multicolumn{2}{|r|}{ Total } & 0.57 & & 1.855615 \\
\hline No & Weaknesses Factor & Weight & Rating & Score \\
\hline 1 & $\mathrm{~W} 1$ & 0.09 & 2 & 0.181818 \\
\hline 2 & W2 & 0.12 & 2.6 & 0.305882 \\
\hline 3 & W3 & 0.10 & 2.4 & 0.24385 \\
\hline 4 & W4 & 0.12 & 1.8 & 0.22139 \\
\hline \multicolumn{2}{|r|}{ Total } & 0.43 & & 0.952941 \\
\hline \multicolumn{2}{|r|}{ Total Weight } & 1.00 & IFAS Total Score & 2.808556 \\
\hline \multicolumn{2}{|r|}{ External } & \multirow{2}{*}{ Weight } & \multirow{2}{*}{ Rating } & \multirow{2}{*}{ Score } \\
\hline No & Opportunities Factor & & & \\
\hline 1 & $\mathrm{O} 1$ & 0.12 & 3.2 & 0.375309 \\
\hline 2 & $\mathrm{O} 2$ & 0.12 & 3.4 & 0.419753 \\
\hline 3 & $\mathrm{O} 3$ & 0.14 & 3.6 & 0.488889 \\
\hline 4 & $\mathrm{O} 4$ & 0.11 & 3.4 & 0.390164 \\
\hline \multicolumn{2}{|r|}{ Total } & 0.37654321 & & 1.526776 \\
\hline
\end{tabular}




\begin{tabular}{ccccc}
\hline No & Threats Factor & Weight & Rating & Score \\
\hline 1 & T1 & 0.14 & 2.2 & 0.298765 \\
2 & T2 & 0.12 & 2.6 & 0.320988 \\
3 & T3 & 0.12 & 2.6 & 0.304938 \\
4 & T4 & 0.12 & 2.8 & 0.328395 \\
5 & T5 & 0.13 & 2.4 & 0.311111 \\
& Total & 0.62345679 & & 1.384699 \\
& Total Weight & & EFAS Total Score & 2.911475 \\
\hline
\end{tabular}

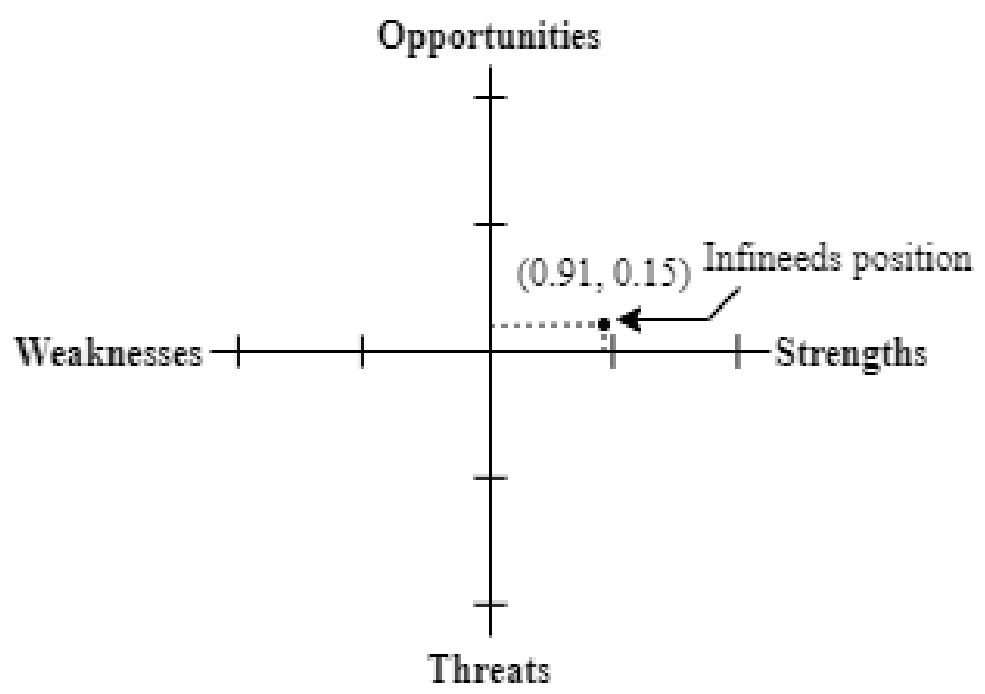

Fig. 5 - SWOT diagram of Infineeds position

Then, the SWOT factors are analyzed using the SWOT matrix and found nine alternative business development strategies strategy as follows:

1. SO Strategy

a) Increased marketing intensity through social media

b) Utilizing other media sources for marketing

c) Using SEO

d) Cooperating with payment gateway providers that provide win-win solutions

2. WO Strategy

a) Mobile application development

b) Maintaining relations by creating a special forum for service providers

3. ST Strategy

a) Pricing policy with competitor benchmarks

b) Research customer needs to get more potential new markets

4. WT Strategy

a) Provide opportunities for each division to explore, especially in the development of technological products

Based on Fig.5, it is recommended for Infineeds to use aggressive strategy (SO strategy), therefore the next step will be focused on four strategies of SO strategy only. These four strategies are then measured to get priority of each strategy by calculating the attractiveness score using QSPM. The results of QSPM data processing are shown in Table 5. 
Table 5 - Alternative strategies priority

\begin{tabular}{ccc}
\hline Strategic & TAS & Ranking \\
\hline Increased marketing intensity through social media & 6.03 & 4 \\
Utilizing paid ads & 6.13 & 3 \\
Using SEO & 6.62 & 1 \\
Cooperating with payment gateway providers & 6.59 & 2 \\
\hline
\end{tabular}

The design of the proposed BMC is carried out based on conformity with the priority of alternative business development strategies that previously had been processed using QSPM based on the company's current position, namely the SO strategy. The proposed BMC can be seen in Table 6.

Several components were added to the proposed BMC as recommendations based on alternative development strategies in SO strategy. There are three of the nine blocks developed for the Infineeds business model with the following descriptions:

1. The most prioritized strategy is using SEO which is contained in the BMC key activities block. Infineeds needs to pay attention from the product development side. Based on this strategy, Infineeds needs to optimize search engines (SEO) for websites. SEO provides customer behavior data to startups including the potential consumer periodically [20].

2. The strategy that is prioritized in the second place is collaborating with payment gateway providers that provide mutual benefits contained in the BMC key partner block. Using a payment gateway provider can provide more value to customers in terms of convenience and security when doing a transaction through Infineeds' website [21].

3. The strategy that is prioritized in the third and fourth place is utilizing paid ads and social media for promotion contained in the BMC channels and key activities block. In this digitalization era, marketing is mostly done through digital marketing media such as Google Ads and Facebook Ads. These kinds of paid ads are great ways to reach potential customers and introduce Infineeds' brand [22]. By posting on Infineeds' social media intensively, the more potential customers know the brand [23].

Table 6 - Proposed BMC

\begin{tabular}{|c|c|c|c|c|c|}
\hline \multicolumn{6}{|c|}{ Proposed BMC for Infineeds } \\
\hline \multirow{2}{*}{$\begin{array}{c}\text { Key } \\
\text { partnership } \\
\text { Laundry } \\
\text { (MSMEs), } \\
\text { laundry } \\
\text { entrepreneur } \\
\text { community and } \\
\text { forum, } \\
\text { Payment } \\
\text { gateway } \\
\text { provider }\end{array}$} & $\begin{array}{c}\text { Key activities } \\
\text { App usage training, quality } \\
\text { standardization, using SEO, } \\
\frac{\text { Promotion using paid ads and }}{\underline{\text { social media }}}\end{array}$ & \multirow{2}{*}{\multicolumn{2}{|c|}{$\begin{array}{c}\text { Value } \\
\text { propositions } \\
\text { Website based } \\
\text { applications, } \\
\text { increase the } \\
\text { productivity of } \\
\text { business } \\
\text { partners }\end{array}$}} & $\begin{array}{c}\text { Customer } \\
\text { relationship } \\
\text { Giveaway, free } \\
\text { education, promo, } \\
\text { and discount }\end{array}$ & \multirow{2}{*}{$\begin{array}{l}\text { Customer } \\
\text { segments } \\
\text { Students, } \\
\text { laundry } \\
\text { (MSMEs) }\end{array}$} \\
\hline & $\begin{array}{l}\text { Key resources } \\
\text { Support system, } \\
\text { Human resources }\end{array}$ & & & $\begin{array}{c}\text { Channels } \\
\text { Social media, print } \\
\text { media, influencer, } \\
\text { online paid ads }\end{array}$ & \\
\hline \multicolumn{3}{|c|}{$\begin{array}{l}\text { Fixed cost (wages, rental of web and server offices, } \\
\text { operations), variable cost (office supplies, advertising, cast, } \\
\text { etc.) }\end{array}$} & \multicolumn{3}{|c|}{$\begin{array}{l}\text { Revenue streams } \\
\text { ption, sharing profit, a convenience fee }\end{array}$} \\
\hline
\end{tabular}

Notes: Underlined items are new items proposed by this research

Comparison of the results with previous research that are [15], [16], [17], and [19] shows that there is a similarity of concern in proposing alternative strategies in terms of promotion even though [19] does not mention which channels use for promoting. This study shows that Infineeds engaged in the laundry marketplace need to use SEO to boost website traffic and it is also similar to [16] that conducted in an outsourcing company. The reason for this similar recommendation is because the studies found that there is an opportunity from SWOT analysis results for those companies to optimize IT when the studies are being conducted. Another recommendation regarding the promotion from this study is utilizing paid 
ads and social media. These strategies have the same results when comparing [15] and [16]. The difference is found in the study by [17] that recommends the fashion SME to promote through an e-marketplace while the object of this study is a company that is already engaged as a marketplace. This study has a very significant difference of results compared to [18] that recommends more in terms of physical location and product development for Coffee Shop Company. These differences are due to both company's internal and external factors when a SWOT analysis is carried out.

The results of the study are then carried out with a final evaluation using the participant method and a questionnaire to the expert judgment, in this case, is the owner of Infineeds. This aims to get approval from the party who best understands the condition of the company that the results of the study can solve the problems. The results of expert judgment validation show that the strategies proposed in this research can be implemented.

\section{Conclusion}

The strategies that need to be considered by Infineeds are; using SEO; cooperating with payment gateway providers; utilizing paid ads and social media for promotion. Using SEO will make it easier for customers to access Infineeds website and can increase website traffic so that the potential users of Infineeds become greater. The same impact will be obtained when utilizing paid ads for promotion by deploying some ads through Google Ads and Facebook Ads. Promotion can also be done by publishing Infineeds' Instagram and Facebook content intensively. This kind of promotion helps Infineeds to improve its brand awareness among potential users. These two strategies will have a combined impact on Infineeds market development. On the other hand, the third strategy, cooperating with payment gateway providers, will provide the user convenience and safety during transactions. By using this strategy, Infineeds can offer unique value to its potential customers because currently there is no similar marketplace that offers transaction features like this.

While beneficial strategies can be extracted out of this research, the extent to which the strategies can be implemented remains to be learned. In addition, the scope of the market of this research is quite limited. The preliminary survey conducted has a limit on the respondents, namely laundry providers and students at Telkom University while the targeted potential customers of Infineeds is all over Indonesia. In future research, it is recommended to reach a larger scope of respondents covering several cities in Indonesia.

\section{Disclaimer}

The authors whose names are written certify that they have no conflict of interest.

\section{References}

[1] M. Munir, "Peran Usaha Kecil dan Menengah ( UKM ) dalam Penciptaan Lapangan Kerja Baru," Jurnal Ekonomi Modernisasi, vol. 1, no. 2, pp. 120-127, 2005.

[2] E. I. Apavaloaie, "The impact of the Internet on the business environment," Procedia Economics and Finance, pp. 951-958, 2014.

[3] D. Ginanjar, "Kemenkominfo: 9,4 Juta UMKM Sudah Go Online," 15 March 2020. [Online]. Available: https://www.jawapos.com/surabaya/15/03/2020/kemenkominfo-94-juta-umkm-sudah-go-online/.

[4] R. S. Septarini and S. M. Husain, "Design Prototype E-service untuk Meningkatkan Pelayanan Binsis UMKM Pada Jenis Usaha Jasa Laundry," Jurnal Teknik Informatika (JIKA) Universitas Muhammadiyah Tangerang, pp. 1-8, 2019.

[5] D. H. Jayani and S. Fitra, "Berapa Sumbangan UMKM Terhadap Perekonomian Indonesia?," 20 May 2020. [Online]. Available: https://databoks.katadata.co.id/datapublish/2020/05/20/berapa-sumbangan-umkm-terhadapperekonomian-indonesia.

[6] wpJakarta, "Insight dan Data Industri Laundry di Indonesia (pengalaman selama 10 tahun QnC Laundry)," 1 August 2020. [Online]. Available: https://wpjakarta.com/blog/insight-dan-data-industri-laundry-di-indonesia-pengalamanselama-10-tahun-qnc-laundry/.

[7] N. Alda and S. Wulandari, "LinkAja Business Models Strategy Development Using BMC Approaches," International Journal of Innovation in Enterprise System (IJIES), vol. 4, no. 2, pp. 46-59, 2020

[8] A. Osterwalder and Y. Pigneur, Business Model Generation, New Jersey: Wiley, 2010.

[9] Tim PPM Manajemen, Business Model Canvas, Jakarta: PPM, 2012.

[10] E. Gurel and M. Tat, "SWOT Analysis: A Theoretical Review," The Journal of International Social Research, Vol.10, Issue: 51, pp. 994-1006, 2017.

[11] F. Rangkuti, Teknik Membedah Kasus Bisnis Analisis SWOT, Jakarta: PT. Gramedia Pustaka Utama, 2015. 
[12] A. F. Anggraini, M. Primyastanto and T. N. Utami, "The Industrial Development of PT. Phillips Seafood Indonesia Pasuruan To Fulfill Basic Material of Crab (Portunus pelagicus)," Econonomic and Social of Fisheries and Marine Journal (ECSOFiM), Vol.4(1), pp. 105-112, 2016.

[13] Suhardi, "Quantitative Strategic Planning Matrix (QSPM)," Jurnal STIE Semarang, Vol.3(1), pp. 14-22, 2011.

[14] S. Nurhayati, "Pendekatan QSPM Sebagai Dasar Perumusan Strategi Pengingkatan Pendapatan Asli Daerah Kabupaten Batang, Jawa Tengah," Jurna Ekonomi Pembangunan, Vol.9(1), pp. 72-82, 2008.

[15] E. C. Tjitradi, "Evaluasi dan Perancangan Model Bisnis Berdasarkan Business Model Canvas," AGORA, vol. III, no. 1, pp. 8-16, 2015.

[16] B. B. Prasetyo, L. M. Baga and L. N. Yuliati, "Strategi Pengembangan Bisnis Rhythm of Empowerment Dengan Pendekatan Model Bisnis Kanvas," Jurnal Aplikasi Manajemen dan Bisnis, vol. IV, no. 2, pp. 296-307, 2018.

[17] K. A. Aziz, S. Wulandari and B. H. Sagita, "Perancangan Model Bisnis UKM Atelier Prana Dengan Menggunakan Pendekatan Business Model Canvas," e-Proceeding of Engineering, vol. V, no. 3, pp. 6828-6833, 2018.

[18] A. Qanita, "Analisis Strategi Dengan Metode SWOT dan QSPM (Quantitative Strategic Planning Matrix): Studi Kasus Pada D'Gruz Caffe di Kecamatan Bluto Sumenep," Jurnal Ilmiah Manajemen, vol. I, no. 2, pp. 11-24, 2020.

[19] N. Kuswardhani, R. Agustian and M. L. Plus, "Strategi Pengembangan Bisnis "COFRESH" Dengan Metode Business Model Canvas (BMC) dan QSPM (Quantitative Strategic Planning Matrix)," Agroindustrial Technology Journal, vol. IV, no. 2, pp. 167-181, 2020.

[20] C. A. Sukandar, "SEO Itu Penting untuk Startup, Ini 7 Alasannya," Warta Ekonomi, 5 April 2019. [Online]. Available: https://www.wartaekonomi.co.id/read222517/seo-itu-penting-untuk-startup-ini-7-alasannya. [Accessed 23 July 2021].

[21] Xendit, "Cara Kerja Payment Gateway dan Penerapannya dalam Bisnis E-Commerce Anda," Xendit, 30 September 2018. [Online]. Available: https://www.xendit.co/id/blog/cara-kerja-payment-gateway-dan-penerapannya-dalambisnis-e-commerce-anda/. [Accessed 23 July 2021].

[22] M. Morgan, "Get Visible: Using Paid Search \& Social for Brand Awareness," The WordStream, 16 May 2019. [Online]. Available: https://www.wordstream.com/blog/ws/2018/09/05/brand-awareness-campaigns. [Accessed 23 July 2021].

[23] Z. Fyefe, "The Benefits of Posting Regularly on Social Media for your Business," The Marketing Folks, 21 April 2021. [Online]. Available: https://themarketingfolks.com/social-media-benefits/. [Accessed 23 July 2021]. 